\title{
A Histological Study of Intrasplenic Transplanted Neonatal Rat Pancreas and of Adjacent Adipose Tissue Proliferation
}

\author{
I. G. Banks ${ }^{1}$, J. M. Sloan ${ }^{1}$ and K. D. Buchanan ${ }^{2}$ \\ Departments of 'Pathology and ${ }^{2}$ Medicine, Queen's University of Belfast, Northern Ireland
}

\begin{abstract}
Summary. Proliferation of adipose tissue adjacent to intrasplenic transplants of whole isogeneic neonatal rat pancreas has consistently been noted. In this study over a period of 18 months there was a progressive increase in the amount of fatty tissue in the vicinity of surviving transplants. Immunohistochemistry demonstrated the presence of insulin, glucagon, somatostatin and pancreatic polypeptide within islet cells in long term grafts. Electron microscopy demonstrated a close association between islets and lipid droplets. Ductal elements within the transplants survived and showed close association with endocrine cells, but exocrine pancreatic tissue degenerated rapidly. Radioimmunoassay of extracts from surviving transplants in isogeneic rats confirmed the presence of high levels of insulin and glucagon after transplantation. In contrast, allogeneic intrasplenic transplants of rat pancreas failed to survive and showed no evidence of adipose tissue proliferation. Furthermore, isogeneic intrasplenic transplants of both adult rat fat and adrenal gland also failed to demonstrate adipocyte proliferation. It would appear that the presence of both adipocytes and pancreatic endocrine cells, particularly B cells, are required for the proliferation of adipocytes at the graft site.
\end{abstract}

Key words: Intrasplenic rat pancreas transplantation, insulin, glucagon, adipose tissue.

The transplantation of pancreatic endocrine tissue is a possible means for the treatment of diabetes mellitus. Whilst there is general agreement that this may improve the metabolic abnormalities in the recipient, there is little knowledge about the long-term effects of high local concentrations of pancreatic hormones on non-pancreatic tissue. In this study an attempt has been made to follow the development of the transplanted neonatal pancreas and the effects of pancreatic transplantation on adipose tissue proliferation at the implant site.

\section{Methods}

The adult $\mathrm{AS}$ or $\mathrm{PVG} / \mathrm{G}$ isogeneic or Wistar allogeneic rats used as recipients were first rendered mildly diabetic by streptozotocin $50 \mathrm{mg} / \mathrm{kg}$ administered IP, as the hyperglycaemic state is reported to have a trophic effect on insulin secreting cells [1]. The animals were then left in metabolic cages for 3 weeks and were allowed food and water ad libitum before and after transplantation. Urine was tested daily for glycosuria and blood glucose levels were estimated every 14 days using Ames Dextrostix and an Ames Eyetone reflectance meter.

A total of 250 animals were used as donors or recipients. Less than $1 \%$ died following streptozotocin administration. Initially, post-operative survival rates were as low as $75 \%$, but later improved to over $90 \%$ with the severely diabetic recipients accounting for most of the fatalities. The severity of diabetes induced by the streptozotocin varied, possibly as a result of the site of administration (IP). The diabetic state was defined in terms of basal fasting blood glucose levels and daily urine production as normal $(3-5 \mathrm{mmol} / \mathrm{l}$, $<10 \mathrm{ml}$ of urine), mild $(6-8 \mathrm{mmol} / 1,10-100 \mathrm{ml})$ or severe $(>$ $8 \mathrm{mmol} / \mathrm{l},>100 \mathrm{ml}$ ) (Tables 1 and 2 ).

Following laparotomy three whole neonatal rat pancreases (1-3 days postpartum) were inserted into the long axis of the host spleen using a wide bore cannula and blunt probe. The development of the transplants was assessed between 1 and 540 days later using both electron microscopy and light microscopy, including immunohistochemistry for insulin, glucagon, somatostatin and pancreatic polypeptide secreting cells (Table 1 ). In addition we used radioimmunoassay to investigate tissue content of glucagonlike immunoreactivity and insulin-like immunoreactivity, in whole spleens of individual animals not included in the histology investigation, up to 280 days after isogeneic and 360 days after allogeneic transplantation (Table 2).

Similàr intrasplenic transplantation of isogeneic adrenal or adipose tissue was carried out, each in a group of ten rats. The transplant sites were examined histologically up to 6 months after transplantation. 
Table 1. Histology of pancreatic transplants

Allogeneic transplants

\begin{tabular}{|c|c|c|c|c|c|c|c|c|c|}
\hline \multirow{2}{*}{$\begin{array}{l}\text { Implantation } \\
\text { time (days) }\end{array}$} & \multirow{2}{*}{$\begin{array}{l}\text { Diabetic } \\
\text { condition }^{\mathrm{a}}\end{array}$} & \multicolumn{8}{|c|}{ Types of cell present in graft } \\
\hline & & $\begin{array}{l}\text { Adipose } \\
\text { cells }\end{array}$ & $\begin{array}{l}\text { Endocrine } \\
\text { cells }\end{array}$ & $\begin{array}{l}\text { Acinar } \\
\text { cells }\end{array}$ & $\begin{array}{l}\text { Ductal } \\
\text { cells }\end{array}$ & A cells & B cells & D cells & PP cells \\
\hline 0 & M & - & + & + & + & + & + & + & + \\
\hline 0 & $\mathrm{M}$ & - & + & + & + & + & + & $?$ & $?$ \\
\hline 0.3 & $\mathrm{~N}$ & - & + & + & + & + & + & + & + \\
\hline 1 & $\mathrm{~N}$ & - & + & + & + & + & + & $?$ & - \\
\hline 1 & M & - & + & + & + & + & + & - & - \\
\hline 2 & $\mathrm{M}$ & - & + & + & + & + & + & - & - \\
\hline 3 & $\mathrm{~N}$ & - & + & - & + & + & + & $?$ & - \\
\hline 3 & $\mathrm{~N}$ & - & $+1-$ & - & + & $?$ & - & - & - \\
\hline 4 & $\mathrm{~N}$ & - & + & - & + & - & + & - & - \\
\hline 4 & $\mathrm{~N}$ & - & + & - & + & $?$ & $?$ & $?$ & $?$ \\
\hline 5 & M & - & - & - & - & - & - & - & - \\
\hline 6 & M & - & + & - & + & $?$ & $?$ & $?$ & $?$ \\
\hline 6 & $\mathrm{M}$ & - & + & - & + & $?$ & $?$ & $?$ & $?$ \\
\hline 7 & $\mathrm{~S}$ & - & + & - & + & - & + & $?$ & $?$ \\
\hline 7 & $\mathrm{~S}$ & - & + & - & + & + & + & $?$ & $?$ \\
\hline 7 & $\mathrm{~S}$ & - & - & - & - & - & - & - & - \\
\hline 8 & $\mathrm{M}$ & - & $+1-$ & - & + & $?$ & $?$ & $?$ & $?$ \\
\hline 9 & $\mathrm{~N}$ & - & + & - & + & + & + & $?$ & $?$ \\
\hline 11 & $\mathrm{~N}$ & - & - & - & + & - & - & - & - \\
\hline 13 & $\mathrm{M}$ & - & - & - & - & - & - & - & - \\
\hline 20 & $\mathrm{~N}$ & $-1+$ & + & - & + & + & + & + & + \\
\hline 20 & $\mathrm{M}$ & - & - & - & - & - & - & - & - \\
\hline 20 & $\mathrm{~S}$ & - & - & - & $+/-$ & - & - & - & - \\
\hline 21 & M & - & - & - & $+1-$ & - & - & - & - \\
\hline 21 & $\mathrm{M}$ & - & - & - & - & - & - & - & - \\
\hline 21 & M & - & - & - & - & - & - & - & - \\
\hline 23 & $\mathrm{~N}$ & - & - & - & + & - & - & - & - \\
\hline 31 & $\mathrm{~N}$ & - & - & - & - & - & - & - & - \\
\hline 330 & $\mathrm{~N}$ & - & - & - & - & - & - & - & - \\
\hline
\end{tabular}

Isogeneic transplants

\begin{tabular}{|c|c|c|c|c|c|c|c|c|c|}
\hline \multirow{2}{*}{$\begin{array}{l}\text { Implantation } \\
\text { time (days) }\end{array}$} & \multirow{2}{*}{$\begin{array}{l}\text { Diabetic } \\
\text { condition }^{\mathrm{a}}\end{array}$} & \multicolumn{8}{|c|}{ Types of cell present in graft ${ }^{b}$} \\
\hline & & $\begin{array}{l}\text { Adipose } \\
\text { cells }\end{array}$ & $\begin{array}{l}\text { Endocrine } \\
\text { cells }\end{array}$ & $\begin{array}{l}\text { Acinar } \\
\text { cells }\end{array}$ & $\begin{array}{l}\text { Ductal } \\
\text { cells }\end{array}$ & A cells & B cells & D cells & PP cells \\
\hline 7 & $\mathrm{~N}$ & - & + & - & + & + & + & $?$ & $?$ \\
\hline 8 & $\mathrm{M}$ & - & - & - & + & - & - & - & - \\
\hline 16 & $\mathrm{M}$ & + & - & - & - & - & - & - & - \\
\hline 30 & $\mathrm{~S}$ & - & - & - & - & - & - & - & - \\
\hline 46 & $\mathrm{~N}$ & + & + & - & + & + & + & + & - \\
\hline 63 & $N$ & + & + & - & + & + & + & - & + \\
\hline 90 & $\mathrm{~N}$ & + & + & - & + & + & + & + & - \\
\hline 90 & $\mathrm{~N}$ & + & + & - & + & + & + & + & - \\
\hline 90 & $\mathrm{~S}$ & + & + & - & + & + & + & + & - \\
\hline 90 & $\mathrm{~N}$ & + & + & - & + & + & + & + & - \\
\hline 90 & $\mathrm{~N}$ & + & + & - & + & + & $?$ & + & - \\
\hline 120 & $N$ & + & + & - & + & + & + & $?$ & + \\
\hline 120 & $\mathrm{M}$ & + & + & - & + & + & $?$ & + & - \\
\hline 120 & $N$ & + & + & - & + & + & + & $?$ & + \\
\hline 150 & $\mathrm{~S}$ & + & + & - & + & $?$ & $?$ & $?$ & $?$ \\
\hline 150 & $\mathrm{~S}$ & + & + & - & + & $?$ & $?$ & $?$ & $?$ \\
\hline 180 & $\mathrm{M}$ & + & + & - & + & + & ? & - & - \\
\hline 190 & $\mathrm{~S}$ & + & + & - & + & + & + & + & - \\
\hline 190 & $\mathrm{~S}$ & + & + & - & + & + & + & + & - \\
\hline 190 & S & + & + & - & + & + & + & + & - \\
\hline 220 & $\mathrm{M}$ & + & + & - & + & + & $?$ & + & - \\
\hline 300 & $\mathrm{~N}$ & + & + & - & + & + & + & + & + \\
\hline 340 & $\mathrm{~N}$ & + & + & - & + & $?$ & $?$ & $?$ & $?$ \\
\hline 340 & $\mathrm{~N}$ & + & + & - & + & + & + & + & - \\
\hline 360 & $N$ & + & + & - & + & + & + & + & - \\
\hline 400 & $N$ & + & + & - & + & + & + & + & - \\
\hline 400 & $\mathrm{~N}$ & + & + & - & + & + & + & + & - \\
\hline 540 & $\mathrm{~N}$ & + & + & - & + & + & + & + & - \\
\hline
\end{tabular}

a $\mathrm{N}$ - normal, $\mathrm{M}$ - mildly diabetic, $\mathrm{S}$ - severely diabetic

b $+/$-- very small numbers observed, ? no attempt or inconclusive results 
Table 2. Amounts of insulin-like and glucagon-like immunoreactivity detected by radioimmunoassay after extraction from individual spleens at various intervals following implantation of pancreas

\begin{tabular}{|c|c|c|c|c|c|c|c|}
\hline \multicolumn{4}{|c|}{ Allogeneic transplant $(n=13)$} & \multicolumn{4}{|c|}{ Isogeneic transplant $(n=20)$} \\
\hline $\begin{array}{l}\text { Implant } \\
\text { period } \\
\text { (days) }\end{array}$ & $\begin{array}{l}\text { Diabetic } \\
\text { condition }^{\mathrm{a}}\end{array}$ & $\begin{array}{l}\text { Glucagon-like } \\
\text { immuno- } \\
\text { reactivity (ng) }\end{array}$ & $\begin{array}{l}\text { Insulin-like } \\
\text { immuno- } \\
\text { reactivity }(\mathrm{mU})\end{array}$ & $\begin{array}{l}\text { Implant } \\
\text { period } \\
\text { (days) }\end{array}$ & $\begin{array}{l}\text { Diabetic } \\
\text { condition }^{\mathrm{a}}\end{array}$ & $\begin{array}{l}\text { Glucagon-like } \\
\text { immuno- } \\
\text { reactivity (ng) }\end{array}$ & $\begin{array}{l}\text { Insulin-like } \\
\text { immunoreactivity } \\
(\mathrm{mU})\end{array}$ \\
\hline 1 & $\mathrm{~N}$ & 16.0 & 18.0 & 2 & $\mathrm{~N}$ & 0.8 & - \\
\hline 2 & $\mathrm{~N}$ & 0.6 & 0.8 & 9 & $\mathrm{~N}$ & 2.4 & - \\
\hline 4 & $\mathrm{~N}$ & 1.2 & 6.0 & 13 & $\mathrm{~N}$ & 16.0 & 40.0 \\
\hline 7 & $\mathrm{~N}$ & 2.8 & 14.0 & 14 & $\mathrm{~N}$ & 7.8 & 17.4 \\
\hline 9 & $\mathrm{~N}$ & 0.1 & 4.7 & 16 & $\mathrm{~N}$ & 2.0 & - \\
\hline 20 & $\mathrm{~N}$ & 8.7 & 13.5 & 20 & $\mathrm{~N}$ & 1.8 & - \\
\hline 39 & $\mathrm{~N}$ & 0.3 & 0 & 30 & $\mathrm{~S}$ & 4.5 & 0 \\
\hline 40 & $\mathrm{~N}$ & 1.3 & - & 30 & $S$ & 0 & 0 \\
\hline 53 & $\mathrm{~N}$ & 0.3 & 0 & 30 & $\mathrm{~S}$ & 76.5 & 4.0 \\
\hline 62 & $\mathrm{~N}$ & 0 & 0 & 41 & $\mathrm{~N}$ & 12.5 & - \\
\hline 75 & $\mathrm{~N}$ & 0 & 0 & 55 & $\mathrm{~N}$ & 17.5 & 7.5 \\
\hline 150 & $\mathrm{~N}$ & 0 & 0 & 90 & $\mathrm{~N}$ & 7.5 & 8.5 \\
\hline \multirow[t]{8}{*}{360} & $\mathrm{~N}$ & 0 & 0 & 90 & $\mathrm{~N}$ & 18.0 & 88.5 \\
\hline & & & & 90 & $\mathrm{~N}$ & 51.0 & 4.6 \\
\hline & & & & 150 & $\mathrm{M}$ & 28.5 & 5.2 \\
\hline & & & & 150 & $\mathrm{~N}$ & 1.0 & - \\
\hline & & & & 250 & $\mathrm{M}$ & 43.5 & 67.5 \\
\hline & & & & 250 & M & 45.0 & 3.4 \\
\hline & & & & 250 & M & 285.0 & 34.5 \\
\hline & & & & 280 & $\mathrm{~N}$ & 540.0 & 3.4 \\
\hline
\end{tabular}

a $\mathrm{N}$ - normal, $\mathrm{M}$ - mildly diabetic, $\mathrm{S}$ - severely diabetic

Control non-implanted spleens: mean glucagon-like immunoreactivity $=0.005 \mathrm{ng}$; mean insulin-like immunoreactivity $=0.015 \mathrm{mU}$

\section{Transmission Electron Microscopy}

Tissue for electron microscopy was fixed for $4-24 \mathrm{~h}$ at $4{ }^{\circ} \mathrm{C}$ in $2.5 \%$ glutaraldehyde buffered to $\mathrm{pH} 7.4$ with Millonig's phosphate buffer $0.1 \mathrm{~mol} / \mathrm{l}$. The tissue was dissected into $1-\mathrm{mm}$ cubes and rinsed for $4-24 \mathrm{~h}$ in phosphate buffer $0.1 \mathrm{~mol} / 1$ containing sucrose $0.2 \mathrm{~mol} / 1$. Following this the blocks were post-fixed in S-collidine buffered osmium tetroxide for $90 \mathrm{~min}$ at room temperature. After several brief rinses in water to remove excess osmium, the blocks were stained in $2 \%$ uranyl acetate for $30 \mathrm{~min}$ before dehydration and embedding in Spurrs' resin.

A one-micron survey section was cut from each block and stained with $0.5 \%$ Toluidine blue in $1 \%$ sodium borate. Areas were selected for further study and ultra-thin sections $80 \mathrm{~nm}$ thick were examined following staining with lead citrate.

\section{Immunohistochemistry}

The spleen was removed, sliced and fixed in modified Susa fixative [2] for $4 \mathrm{~h}$, washed in $70 \%$ alcohol and processed for wax embedding. Immunohistochemistry was carried out on dewaxed $4-\mu$ paraffin-embedded sections for insulin, glucagon, somatostatin and pancreatic polypeptide. The Sternberger specific indirect antibody peroxidase method was applied [3]. The following antisera were used: GP9 for insulin, raised in guinea-pigs; YY118 for glucagon, raised in rabbits; $O B 2$ for somatostatin, raised in rabbits; and pancreatic polypeptide PP204, raised in rabbits. Antisera were incubated with an excess of the relevant hormone to act as specific blocking controls, and the antisera were used at dilutions of $1: 10$ to $1: 100$. Normal adult rat pancreas and non-implanted spleen were used as positive and negative controls respectively.
The specificity of the antibodies was checked in radioimmunoassay. The insulin antibody cross-reacted with extracts of rat pancreas and also with proinsulin. The glucagon antibody showed negligible cross-reactivity with secretin, vasoactive intestinal polypeptide and gastric inhibitory polypeptide. The somatostatin antibody did not react with any of these gastrointestinal hormones, nor did the antibody to pancreactic polypeptide.

\section{Extraction and Hormonal Content of Spleen}

The whole spleen from test and control animals was chilled immediately after excision and all subsequent manipulations were carried out at $4^{\circ} \mathrm{C}$. The spleen was finally sliced and extracted overnight by eight volumes of a mixture of ethanol and $\mathrm{HCl} 0.7 \mathrm{~mol} / \mathrm{I}(3: 1$ $\mathrm{v} / \mathrm{v}$ ). Then the mixture was centrifuged at $3,000 \mathrm{~g}$ for $30 \mathrm{~min}$, the $\mathrm{pH}$ was adjusted to 7.5 with ammonia solution and the resultant precipitate was removed by centrifugation. The extract was then dried in a jet of air. The samples were reconstituted for radioimmunoassay in sodium phosphate buffer $0.4 \mathrm{~mol} / 1, \mathrm{pH} 7.4$.

\section{Insulin Radioimmunoassay}

The antibody (GP25) was raised in guinea-pigs against porcine insulin and was used at a final dilution of $1: 280,000$ in the assay tube. The antibody cross-reacted with porcine proinsulin to approximately $50 \%$ on a weight basis. Insulin was labelled with ${ }^{125}$ I (Radiochemical Centre, Amersham, Bucks, UK) and purified on microfine silica. The assay can detect $0.5 \mathrm{mU} / 1$ of insulin. 

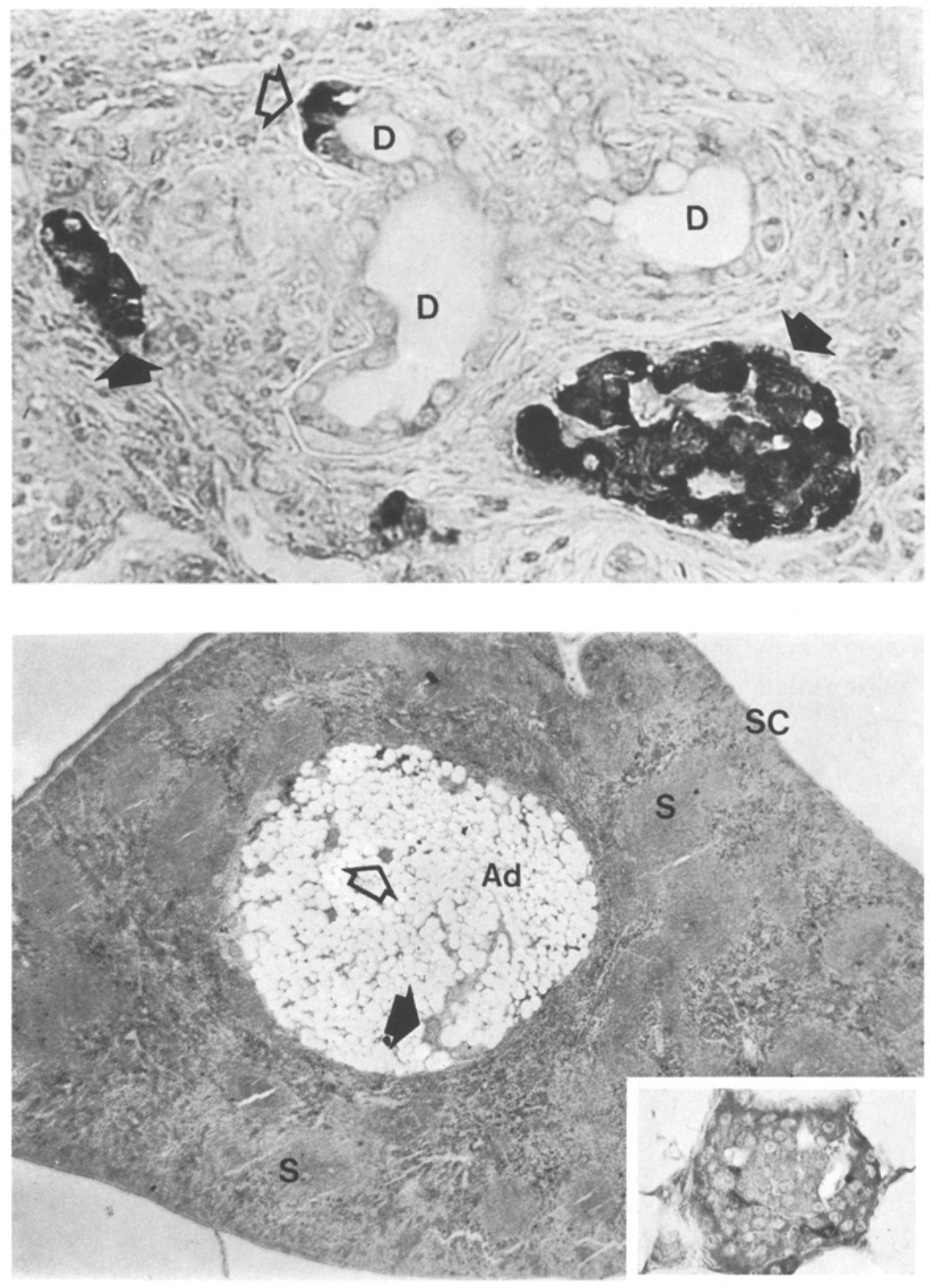

Fig. 1. Light micrograph: 64-day isogeneic neonatal pancreas transplant, immunohistochemically stained for insulin. There is no regeneration of exocrine tissue. The small islets contain strongly staining $B$ cells (closed arrow). There are two positively stained cells within the epithelium of one ductal element (open arrow). $D=$ duct. Immunoperoxidase and Methylene blue counterstain $(\times 560)$

Fig. 2. Low power light micrograph ( $\times$ 19.3): transverse section of host spleen $(S)$ with a 350 -day isogeneic neonatal pancreatic transplant, immunohistochemically stained for somatostatin. Immunoperoxidase and Methylene blue counterstain. The central region of the spleen is occupied by the graft which is composed mainly of adipocytes $(A d)$ and small islets (arrows). The graft is well vascularised. $S C=$ splenic capsule. Islet indicated by open arrow shown at high power Inset $(\times 580)$

\section{Glucagon Radioimmunoassay}

Antibodies raised to pancreatic glucagon were used in the glucagon assay, namely YY89 at a final dilution of $1: 45,000$. YY89 reacts with the C-terminal region of glucagon [4]. The assay can detect glucagon $10 \mathrm{ng} / 1$. No cross-reaction has been noted with other gut and islet hormones, including insulin.

\section{Results}

\section{Blood Glucose Levels}

Three weeks following streptozotocin administration, the blood glucose levels of the animals ranged from $5-12 \mathrm{mmol} / \mathrm{l}$.

\section{Allogeneic Transplants}

There was rapid degeneration of the exocrine mass within the pancreatic transplant, with few cells remaining 2 days after implantation. The endocrine and ductular tissue were retained for up to 20 days and there were no detectable amounts of extractable peptide 52 days beyond transplantation (Table 2). There was no evidence of any exocrine, endocrine or ductular regeneration for up to 1 year after implantation. Furthermore, there was no evidence of adipose proliferation throughout the transplant period, only a small fibrous scar remaining at the implantation site. 


\section{Isogeneic Transplants}

There was similar rapid degeneration of the exocrine mass with few cells remaining 2 days after implantation. At 7 days only endocrine and hollow spheroids of ductular tissue remained within the implant. After a marked initial reduction 1 day following transplantation, variable but significant amounts of extractable immunoreactive peptides were obtained from the grafts (Table2). The amounts of extractable insulin varied considerably and were in general low. However significant amounts were still detectable in grafts up to 280 days old showing that insulin was still being produced. Glucagon levels increased considerably towards the end of the graft period. After transplantation periods in excess of 1 year, glucagon, somatostatin and insulin secreting cells were identified in considerable numbers, usually in small islets often composed of single cell types. Pancreatic polypeptide cells were identified less frequently and were apparently absent from many grafts. Electron microscopy confirmed the presence of these islets. Throughout the transplant period, insulin, glucagon, somatostatin and occasionally pancreatic polypeptide cells were identified immunohistochemically within the ductal epithelium, which was often in close association with small islets (Fig. 1).

A striking feature of the development of the transplants was the proliferation of adipose tissue closely associated with the surviving islets. This was noted after 1 month from implantation and often occupied the major part of the central region of the host spleen after 1 year (Fig. 2). Islets were found in and around the fatty mass, usually associated closely with blood capillaries. The adipocytes were increasingly distended with intracellular lipid throughout the transplant period. Appearances suggestive of lipogenesis were seen in adipocytes in close association with $\mathrm{B}$ cells (Fig. 3), a feature not noted adjacent to a heterogenous group of islet cells or to A cells alone.

There was no proliferation of adipocytes in control transplantations of isogeneic adult rat fat or adrenal gland.

\section{Discussion}

The development of transplanted isogeneic and allogeneic neonatal pancreas has been investigated by a large number of authors, and the spleen has often been chosen as the site of implantation [5-8]. There is general agreement that while allogeneic tissue fails to survive, isogeneic endocrine tissue is retained for considerable periods $[6,7]$. This study demonstrates the ability of ductal elements not only to survive within an

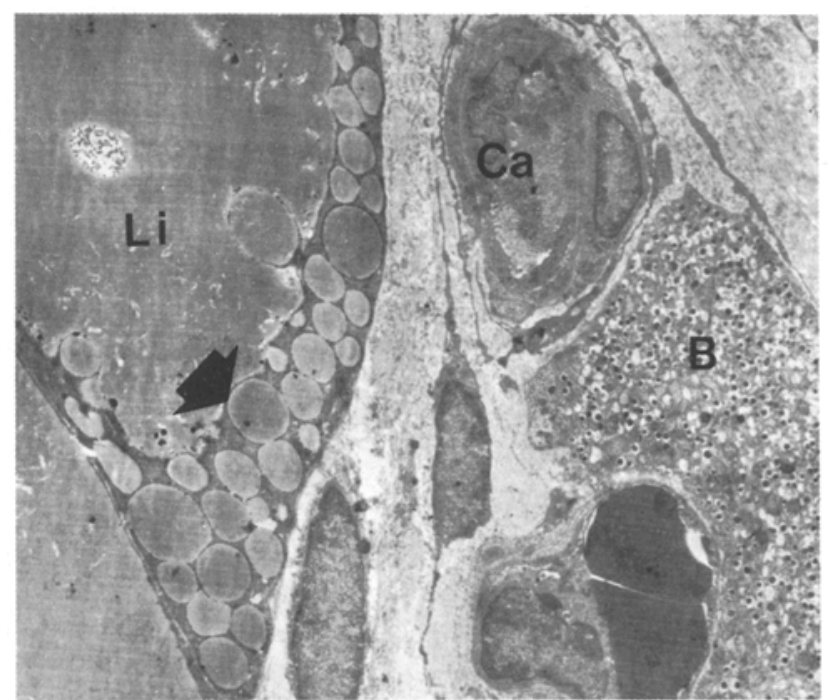

Fig.3. Electron micrograph: 300-day isogeneic neonatal pancreas transplant. B cells are in close association with a number of capillaries $(\mathrm{Ca})$ and an adipocyte. The adipocyte has a number of small intracellular coalescent lipid droplets $(\mathrm{Li})$; arrow in the cytoplasm adjacent to the B cell $(B)$. Uranyl acetate and lead citrate stain $(\times 600)$

isogeneic host, but also the intimate association of endocrine cells with the duct lumen. The presence of endocrine cells within the duct epithelium of pancreas, whether transplanted, organ cultured or in situ, has been reported by a number of authors [9-12], and it would appear that this capacity is not lost after transplantation. There was an apparent increase in the number of endocrine cells within the grafts and this was supported by significant amounts of immunoreactive polypeptide extracted from the graft site. Ductal production of endocrine tissue would ensure the continued presence of active hormone secreting cells and associated high local concentrations of pancreatic hormones within the surrounding tissue.

A rapid and marked proliferation of adipocytes occurred one month after implantation and this may be linked closely to the continued production of hormones within the graft, as it has been shown that there is a close association between pancreatic hormones and lipid metabolism [13, 14]. The cells may originate from adipocytes within the host spleen but are more likely to be derived from the small number of lipid cells within the original implant and may explain why authors using separated (and presumably adipocytefree) islets for transplantation fail to record any similar proliferation at the intrasplenic site $[5,8]$. Indeed prior organ culture of whole foetal pancreas eliminates or reduces fatty proliferation within renal subcapsular or intraperitoneal transplants $[15,16]$. The fact that the neonatal pancreas contains very few adipocytes points to a strong trophic effect within the 
graft on lipogenesis and fatty tissue proliferation. Adipocyte proliferation has been reported by a number of authors transplanting whole fetal pancreas to the renal capsule or anterior chamber of the eye [15, 17-20]. Electron microscopic evidence in this study suggests that there may be a localised action of B cell secretions on lipogenesis within closely associated adipocytes, together with a general trophic effect within the graft, an observation which is consistent with the known lipogenic actions of insulin [13]. The morphological appearance of the adipocytes adjacent to B cells within the graft is similar to that of developing fatty tissue [22].

Acknowledgements. We gratefully acknowledge the technical assistance given by Mr. J. Reid, Mr. P. Maxwell, Mr. C. Carland, Mr. M. Hamilton, Mr. B. Tracey, Dr. S.Cameron and his colleagues, Miss M.O'Hare, Mrs. K. Hanna, Mrs. I. Huda and Mrs. D. Stewart. We are indebted to Miss B. O'Hare for secretarial assistance. This study was supported in part by a grant from the British Diabetic Association.

\section{References}

1. Mosimann F, Mircovitch V, Maccerone-Palmieri R, Blanc D, Campiche $M$ (1978) Is functional demand a condition without which the pancreatic autotransplant cannot survive in the dog's spleen? Helv Chir Acta 45: 157-159

2. Shaw C, Sloan JM, Titterington O (1978) A simple technique for the demonstration of polypeptide secreting cells in human small-intestinal biopsies. Gut 19:979

3. Sternberger LA, Hardy PH (Jr), Cuculis JJ, Meyer HG (1970) The unlabelled antibody enzyme method of immunohistochemistry. Preparation and properties of soluble antigen-antibody complex, (horseradish peroxidase - anti-horseradish peroxidase) and its use in identification of spirochetes. J Histochem Cytochem 18:315-333

4. Flanagan RWJ, Buchanan KD, Murphy RF (1974) Specificity of antibodies in the radioimmunoassay of glucagon. Diabetologia 10:365

5. Koncz L, Zimmerman CE, DeLellis RA, Davidoff F (1976) Transplantation of pancreatic islets into the spleen of diabetic rats and subsequent splenectomy. Transplantation $21: 427-429$

6. Finch DRA, Wise PH, Morris PJ (1977) Successful intrasplenic transplantation of syngeneic and allogeneic isolated pancreatic islets. Diabetologia 13: 195-199

7. Franklin WA, Schulak JA, Reckard CR (1979) The fate of transplanted pancreatic islets in the rat. Am J Pathol 94: 85-96
8. Feldman SD, Hirshberg GE, Dodi G, Raizman ME, Scharp DW, Ballinger WF, Lacey PE (1977) Intrasplenic islet isografts. Surgery 82:386-394

9. Richardson KEY, Spooner BS (1977) Mammalian pancreas development: Regeneration and differentiation in vitro. Dev Biol 58: $402-420$

10. Schweisthal MR, Frost CC (1976) A, D, B, cells and a fourth cell type in long term cultures of fetal rat pancreas. In Vitro 12: $814-820$

11. Lazarow A, Wells LJ, Carpenter A-M, Hegre OD, Leonard RJ, McEvoy RC (1973) Islet differentiation, organ culture and transplantation. Diabetes 22: 877-912

12. Dorn A, Lorentz D, Koch G (1977) Immunohistochemical evidence of insulin and glucagon in the epithelium of the pancreatic duct. Acta Histochem Jena 58: 364-367

13. Renold AE, Crofford OB, Stauffacher W, Jeanrenand B (1965) Hormonal control of adipose tissue metabolism with special reference to the effects of insulin. Diabetologia 1:4-12

14. Lefebvre P (1975) Glucagon and adipose tissue. Biochem Pharmacol 24: 1261-1266

15. Hegre OD, Leonard RJ, Rusin JD, Lazarow A (1976) Transplantation of the fetal rat pancreas. Quantitation morphological analysis of islet tissue growth. Anat Rec 185: 209-222

16. Weber CJ, Reemtsma K, Greenwood MRC (1980) Pancreatic and peri-islet fat. N Engl J Med 302:695

17. McEvoy RC, Hegre OD (1979) Syngeneic transplantation of fetal pancreas. III. Effect of insulin treatment on the growth and differentiation of the pancreatic implants after reversal of diabetes. Diabetes 28: 141-146

18. McEvoy RC, Hegre OD (1978) Syngeneic transplantation of fetal rat pancreas. II. Effect of insulin treatment on the growth and differentiation of pancreatic implants fifteen days after transplantation. Diabetes 27:988-995

19. Brown J, Clarke WR, Molnar IG, Mullen Y (1976) Foetal pancreas transplantation for reversal of streptozotocin induced diabetes in rats. Diabetes 25: 56-64

20. Hegre OD, Leonard RJ, Erlandsen SL, McEvoy RC, Parsons JA, Elde RP, Lazarow A (1976) Transplantation of islet tissues in the rat. Acta Endocrinol 83 (Suppl 205): 257-281

21. Coupland RE (1960) The survival and growth of pancreatic tissue in the anterior chamber of the eye of the albino rat. J Endocrinol 20:69-77

22. Rhodin JAG (1974) Histology. In: Rhodin JAG (ed) A text and atlas. Oxford University Press, p 168

Received: 9 April 1981

and in revised form: 6 October 1981

Dr. Ian Banks

Institute of Pathology

Queen's University of Belfast

Grosvenor Road

Belfast BT12 6BL, Northern Ireland 